\title{
hMSH2 is the most commonly mutated MMR gene in a cohort of Greek HNPCC patients
}

\author{
A Apessos', M Mihalatos', I Danielidis², G Kallimanis², NJ Agnantis ${ }^{3}$, JK Triantafillidis ${ }^{4}$, G Fountzilas ${ }^{5}$, \\ PA Kosmidis ${ }^{6}$, E Razis ${ }^{7}$, VA Georgoulias ${ }^{8}$, HeCOG ${ }^{9}$, HeHeGI ${ }^{10}$ and G Nasioulas ${ }^{*, 1}$ \\ 'Molecular Biology Research Center HYGEIA - 'Antonis Papayiannis', Kifissias Ave \& Erythrou Stavrou 4 Str, 15123 Maroussi, Athens, Greece; \\ ${ }^{2}$ Gastroenterology Department, DTCA HYGEIA, Athens, Greece; ${ }^{3}$ Department of Pathology, Medical School, University of loannina, Greece; ${ }^{4}$ Department \\ of Gastroenterology, Peripheral General Hospital of Nikaia, Greece; ${ }^{5}$ Aristotle University of Thessaloniki, Greece; ${ }^{6}$ 2nd Pathology - Oncology Clinic, DTCA \\ HYGEIA, Athens, Greece; ${ }^{7}$ Ist Pathology - Oncology Clinic, DTCA HYGEIA, Athens, Greece; ${ }^{8}$ Medical School of the University of Crete, Heraklion, Crete, \\ Greece
}

Germline mutations in genes encoding proteins involved in DNA mismatch repair are responsible for the autosomal dominantly inherited cancer predisposition syndrome hereditary nonpolyposis colorectal cancer (HNPCC). We describe here analysis of hMLHI and $h M S H 2$ in nine Greek families referred to our centre for HNPCC. A unique disease-causing mutation has been identified in seven out of nine (78\%) families. The types of mutations identified are nonsense (five out of seven) (hMLHI: E557X, R226X; hMSH2: Q I58X, R359X and R7IIX), a 2 bp deletion (hMSH2 1704_I705delAG) and a 2.2 kb Alu-mediated deletion encompassing exon 3 of the hMSH2 gene. The majority of mutations identified in this cohort are found in hMSH2 (77.7\%). Furthermore, four of the mutations identified are novel. Finally, a number of novel benign variations were observed in both genes. This is the first report of HNPCC analysis in the Greek population, further underscoring the differences observed in the various geographic populations. British Journal of Cancer (2005) 92, 396-404. doi: I 0.I038/sj.bjc.6602260 www.bjcancer.com Published online II January 2005

(c) 2005 Cancer Research UK

Keywords: HNPCC; hMLHI; hMSH2; Greece; rearrangements; MLPA

Hereditary nonpolyposis colorectal cancer (HNPCC) is the most common inherited syndrome predisposing to colorectal cancer (CRC), accounting for 5-10\% of the total CRC (Lynch and de la Chapelle, 1999; MIM 114500). Hereditary nonpolyposis colorectal cancer is characterised by early-onset CRC (mean age at diagnosis $\sim 45$ years) and an increased incidence of cancer in other organs such as the endometrium, stomach, small bowel, ovary, hepatobiliary tract, renal pelvis and ureter (Watson and Lynch, 1993; Lynch and de la Chapelle 1999).

Hereditary nonpolyposis colorectal cancer segregates in an autosomal dominant manner and it is caused by germline mutations in a group of genes encoding proteins involved in the DNA mismatch repair (MMR) pathway. At least five genes of the pathway, namely hMLH1, hMSH2, hMSH6, hPMS1 and hPMS2, have been implicated in HNPCC (Leach et al, 1993; Papadopoulos and Lindblom, 1997; Peltomäki and Vasen, 1997). However, the majority of mutations $(\sim 90 \%)$ have been identified in $h M L H 1$ ( $\sim 50 \%)$ and $h M S H 2(\sim 40 \%)$. Germline mutations that have been identified in $h M L H 1$ and $h M S H 2$ are scattered throughout the coding regions of the two genes with no obvious phenotype-

*Correspondence: Dr G Nasioulas; E-mail: g.nasioul@hygeia.gr

${ }^{9}$ Hellenic Cooperative Oncology Group, H Kalofonos, University of Patras, E Briasoulis, Medical School, University of loannina, D Skarlos, Er Dinnan Hospital, Athens, Greece.

${ }^{10}$ Hellenic Hereditary Gastro-Intestinal Group, H Dervenis, Ist surgical Department 'Agia Olga' Hospital, E Samantas, GOHK 'Agioi Anargyroi', D Tzaninis, 6th IKA of Athens, Greece.

Received I 5 July 2004; revised II October 2004; accepted I8 October 2004; published online II January 2005 genotype correlation. The majority of mutations identified are small insertions/deletions leading to frameshifts and truncated protein products. In addition, a large number of nonsense mutations have been identified (Peltomäki and Vasen, 1997). In recent years, an increasing number of reports have shown that $\sim 10-30 \%$ of mutations responsible for HNPCC are large genomic rearrangements affecting one or more exons of the two genes (Wijnen et al, 1998; Gille et al, 2002; Wagner et al, 2003). This, in addition to the genetic heterogeneity and clinical variability among HNPCC families, makes identification of germline mutations in families suspected to suffer by HNPCC laborious and time consuming. Use of tissue microarray immunohistochemistry expression analysis can help pinpoint the affected gene thereby targeting mutation screening directly to that gene, cutting down on cost and time of analysis (Hendriks et al, 2003; Jourdan et al, 2003; Hardisson et al, 2003). However, characterisation of the disease causing mutation in afflicted families is essential as it allows identification of carrier relatives, who may require appropriate surveillance and alleviates noncarrier individuals from costly and intrusive surveillance.

\section{MATERIALS AND METHODS}

\section{Patients}

To date, 64 individuals from 28 Greek families with CRC were referred to our centre through the Oncology and Gastroenterology Departments of the Diagnostic and Therapeutic Center of Athens HYGEIA and other hospitals throughout Greece. Following an interview with as many family members as possible, a detailed 
Table I Variants identified in the $h M L H I$ and $h M S H 2$ genes during this study

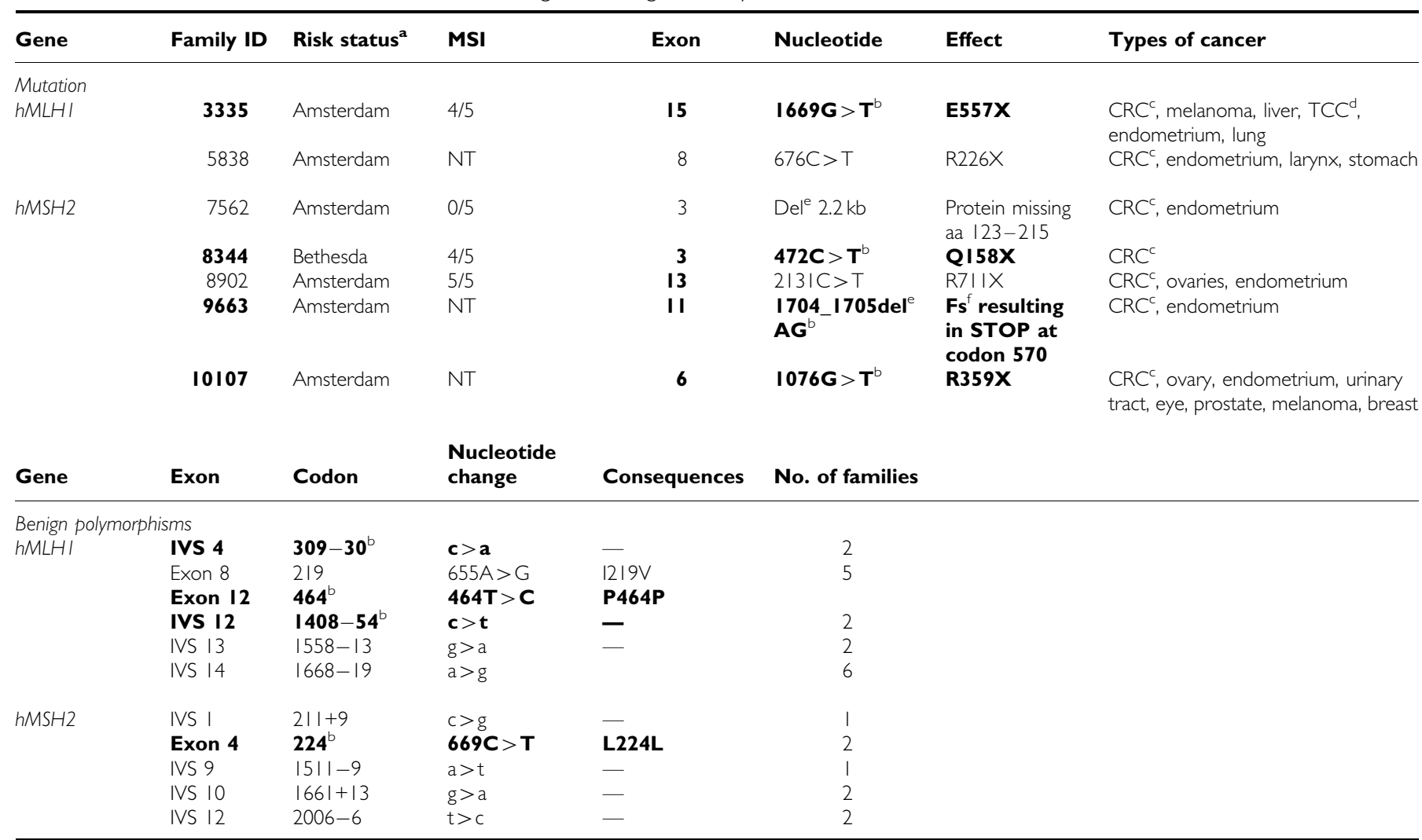

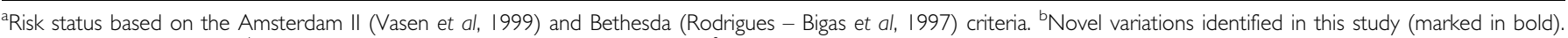
${ }^{\mathrm{c}} \mathrm{CRC}=$ colorectal cancer. ${ }^{\mathrm{d}} \mathrm{TCC}=$ transitional cell carcinoma. ${ }^{\mathrm{e}} \mathrm{Del}=$ deletion. ${ }^{\mathrm{f}} \mathrm{Fs}=$ frame shift mutation.

family tree is constructed. This is then reviewed by three independent scientists in the laboratory in order to make a decision on the risk of the family to be affected by HNPCC. Based on the Amsterdam II (Vasen et al, 1999) and/or Bethesda Criteria (Rodriguez-Bigas et al, 1997), nine of the 28 families were selected for molecular analysis of $h M L H 1$ and $h M S H 2$. The study population, therefore, consisted of seven Amsterdam positive families, one Bethesda positive and one family who did not meet the criteria but were included due to the clustering of CRC.

Screening has been completed in 30 individuals from nine families. Testing was initially carried out on DNA from an affected family member and upon detection of an inactivating mutation the rest of the family members were directly tested for this mutation.

Due to the large proportion of genomic rearrangements that have been shown to be responsible for HNPCC, analysis is initially carried out using multiplex ligation-dependent probe amplification (MLPA) for screening for such mutations in $h M L H 1$ and $h M S H 2$. If a genomic rearrangement is not detected then PCR for all exons and splice junctions of the two genes is carried out. Screening for point mutations and small insertions/deletions is carried out in the majority of amplicons using denaturing high-performance liquid chromatography (dHPLC). Denaturing high-performance liquid chromatography is not carried out for exons containing polymorphic repeats, that is, $h M L H 1$ exon 12 and $h M S H 2$ exons 2 and 5. These three exons and all those indicated by an abnormal dHPLC elution profile are subjected to cycle sequencing.

\section{DNA and RNA isolation}

Genomic DNA and RNA were purified from peripheral blood leukocytes or tissue using standard extraction protocols.

\section{Multiplex ligation-dependent probe amplification (MLPA)}

Multiplex ligation-dependent probe amplification was carried out using the P003 MSH2/MLH1 kit (MRC-Holland, Netherlands) as instructed by the manufacturer. Fragment analysis was carried out on the ABI Prism ${ }^{\circledR} 310$ Genetic Analyzer using TAMRA-500 as size standard. A peak pattern of 42 peaks ranging in size from 130 to $472 \mathrm{nt}$ is obtained (Gille et al, 2002).

\section{PCR amplification}

The complete coding sequence of $h M L H 1$ and $h M S H 2$ including splice junctions was amplified by PCR. Primers used have been described by others (Holinski-Feder et al, 2001). Reactions of $50 \mu \mathrm{l}$ were heated on a PTC-200 MJ Research Thermocycler (MJ Research Inc, USA) at $95^{\circ} \mathrm{C}$ for 5 min then cycled 35 times of denaturation at $95^{\circ} \mathrm{C}$ for $40 \mathrm{~s}$, annealing at the appropriate temperature for $30 \mathrm{~s}$ and extension at $72^{\circ} \mathrm{C}$ for $30-60 \mathrm{~s}$, followed by a final extension step at $72^{\circ} \mathrm{C}$ for $6 \mathrm{~min}$. Reaction mixture was $20 \mathrm{~mm}$ Tris $\mathrm{HCl}(\mathrm{pH} 8.4), 50 \mathrm{mM} \mathrm{KCl}, 1.5 \mathrm{mM} \mathrm{Mg}^{2+}, 200 \mu \mathrm{M}$ each dNTP, 1.5 U Taq DNA polymerase (Invitrogen, UK) or 2.5 U Optimase polymerase (Transgenomic) and $15 \mathrm{pmol}$ of each primer.

\section{Denaturing high-performance liquid chromatography analysis}

The WAVE DNA Fragment Analysis System (Transgenomic, Inc, USA) and associated WAVE-Maker ${ }^{\mathrm{TM}}$ software were used as previously described (Mihalatos et al, 2003a). 


\section{Sequence analysis}

Purification of the PCR products was performed using the Concert Rapid PCR purification or gel extraction system kits (Marligen
Biosciences Inc, USA). Automated cycle sequencing for both strands was performed with the ABI Prism ${ }^{\mathbb{R}} 310$ Genetic Analyzer using the BigDye Terminator Cycle Sequencing kit. Sequences obtained were aligned, using Sequencher ${ }^{\mathbb{R}}$ PC software

A $3335-E 557 X$ in $h M L H 1$

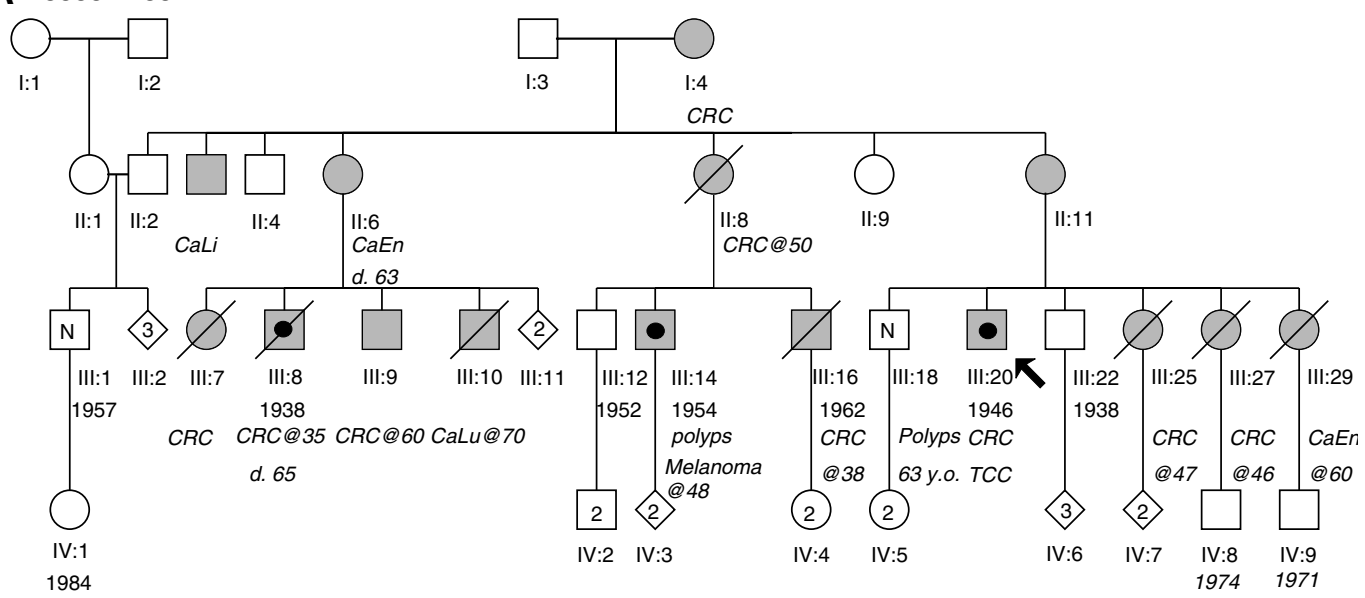

B $8344-\mathrm{Q} 158 \mathrm{X}$ in $h M S H 2$

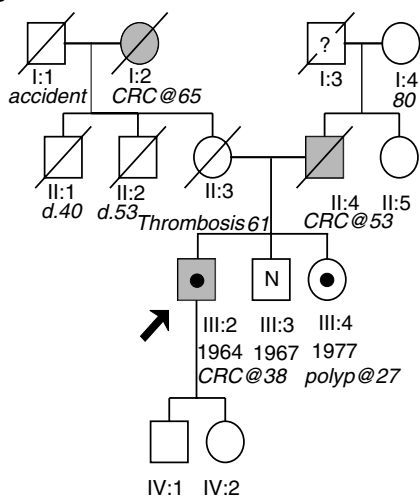

D

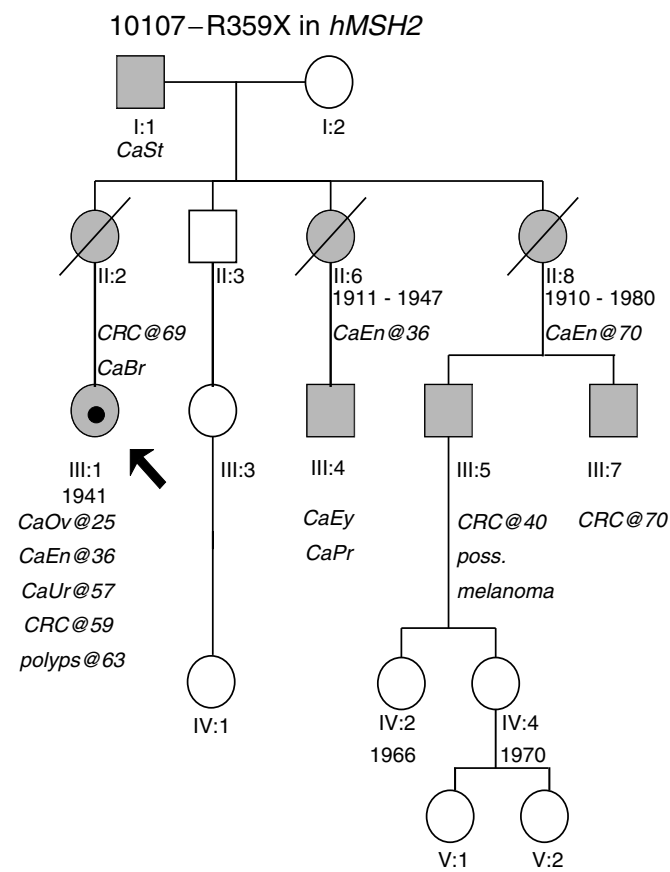

C 9663-1704_1705del AG in $h M S H 2$

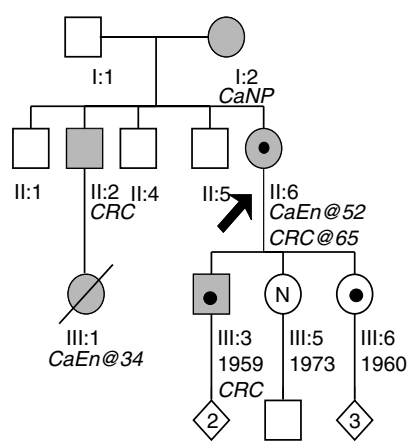

E $7562-h M S H 2$ deletion exon 3

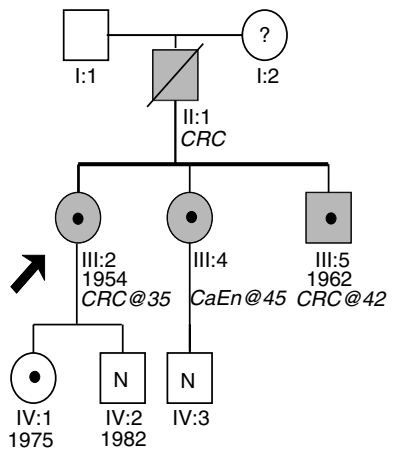

Figure I (Continued) 
F $5838-\mathrm{R} 226 \mathrm{X}$ in $h M L H 1$

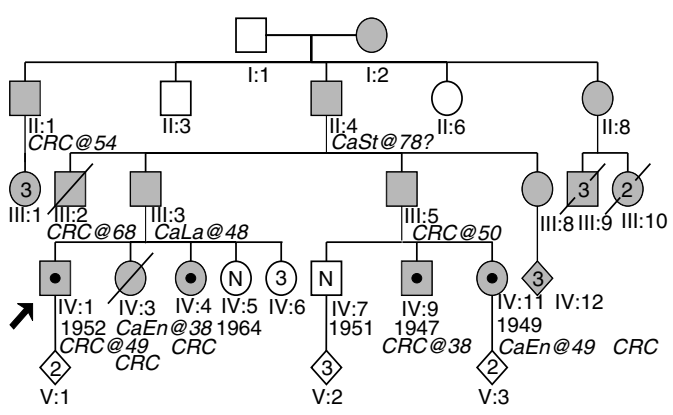

G $\quad 8902-\mathrm{R} 711 \mathrm{X}$ in $h M S H 2$

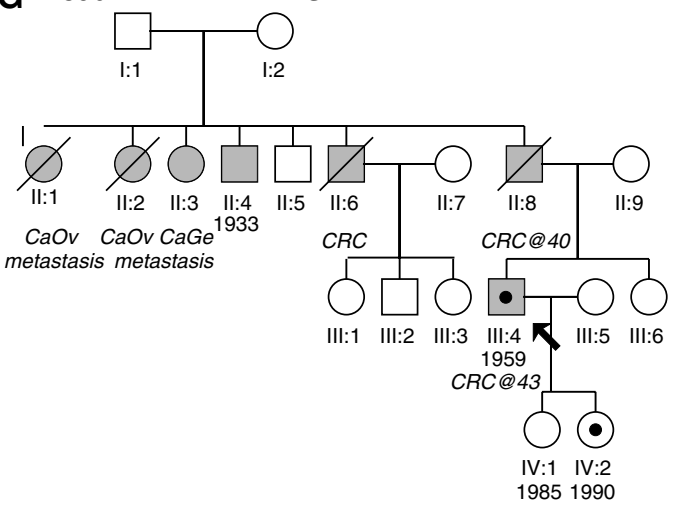

\section{H 6071-no mutation identified}

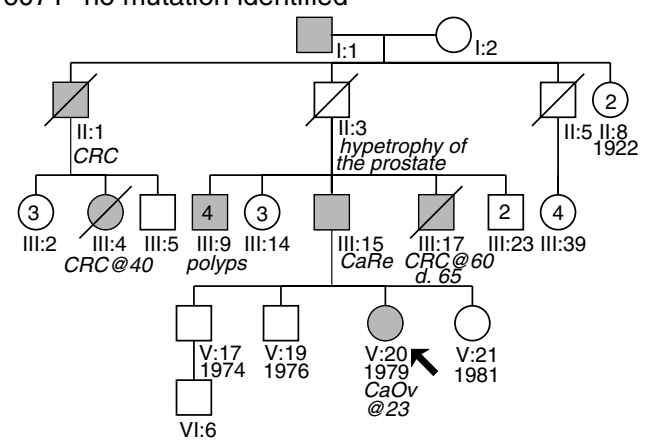

I 9659-no mutation identified

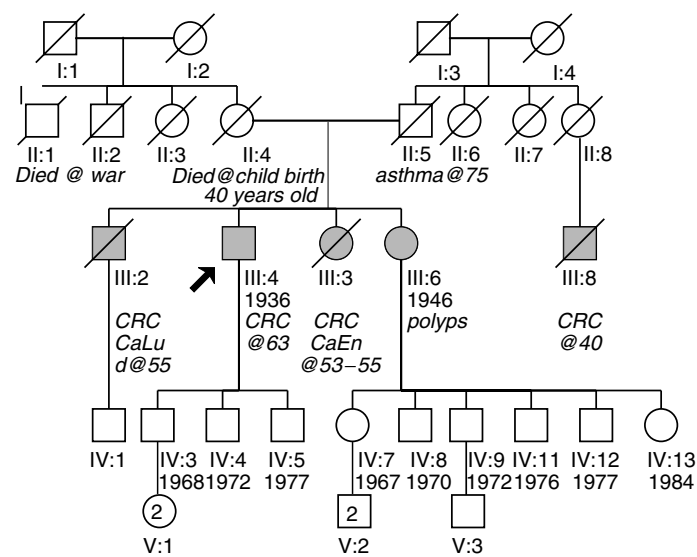

Figure I Pedigrees of families investigated for germline mutations of the $h M L H I$ and $h M S H 2$ genes. Grey symbols indicate individuals with cancer. The proband is indicated by an arrow. A black circle inside a symbol indicates individuals found to carry the mutation. $\mathrm{N}=$ individual tested for the family mutation and was found to be of normal genotype. CRC = colorectal cancer, CaEn=endometrial cancer, CaLi=liver cancer, CaLu=lung cancer, $\mathrm{TCC}=$ transitional cell carcinoma, $\mathrm{CaNP}=$ nasopheryngeal cancer, CaSt $=$ stomach cancer, $\mathrm{CaOv}=$ ovarian cancer, CaEy $=$ cancer of the eye, $\mathrm{CaPr}=$ prostate cancer, poss. $=$ possibly, $\mathrm{CaLa}=$ cancer of the larynx, $\mathrm{CaGe}=$ 'gynaecological' cancer, $\mathrm{CaRe}=$ cancer of the rectum.

(Gene Codes, USA), with normal sequences from Genbank and ENSEMBL (hMLH1: AY217549; hMSH2: ENSEMBL ENST00000233146) and examined for the presence of mutations. All nucleotide numbers refer to the wild-type cDNA.

\section{Long PCR}

The deletion in $h M S H 2$ exon 3 was confirmed by long PCR using the Expand High Fidelity PCR System (Roche, Germany) according to the manufacturer's instructions. PCR products were separated by agarose gel electrophoresis and visualised by EtBr staining.

\section{RT - PCR}

Total RNA was extracted from peripheral blood leukocytes of patients from family D using Trizol (Life Technologies, UK), according to the manufacturer's instructions. First-strand synthesis was performed by denaturing approximately 500-1000 ng total RNA and random hexamers ( $5 \mu \mathrm{m}$ final concentration) for $4 \mathrm{~min}$ at $70^{\circ} \mathrm{C}$, followed by snap freezing on ice and addition of dNTPs ( $0.5 \mathrm{~mm}$ final concentration), $1 \mathrm{U}^{-1} \mathrm{l}^{-1}$ recombinant RNase inhibitor (Invitrogen, UK) and $200 \mathrm{U}$ MMLV reverse transcriptase (Invitrogen, UK). The mixture was incubated at $37^{\circ} \mathrm{C}$ for $1 \mathrm{~h}$ followed by denaturation of the enzymes at $95^{\circ} \mathrm{C}$ for $5 \mathrm{~min}$. In total, $4 \mu \mathrm{l}$ of cDNA were used for subsequent PCR amplification.

\section{RESULTS}

To date, 30 individuals from nine Greek families at high risk of having HNPCC, have been screened to our centre for genetic testing. Of these, MSI analysis was carried out in six patients for whom matching normal and tumour tissue was available.

Our strategy is based on an initial screening of genomic DNA for large genomic rearrangements of $h M L H 1$ and $h M S H 2$ using the recently described method MLPA (Schouten et al, 2002). If a rearrangement is not detected, PCR amplification of all exons and splice junctions of the two genes is carried out, using primers previously described by others (Holinski-Feder et al, 2001). For the majority of amplicons, dHPLC is used as a mutation screening test, followed by direct sequencing for characterisation of mutations indicated by dHPLC. Denaturing high-performance liquid chromatography was not carried out for amplicons containing repetitive polymorphic sequences, that is, exon 12 of $h M L H 1$ and exons 2 and 5 of $h M S H 2$.

In seven families $(3335,5838,7562,8344,8902,9663$ and 10107 in Table 1), seven different mutations have been identified. Four of the mutations are novel nonsense mutations in the $h M L H 1$ and hMSH2 genes. One family (7562 in Table 1) carries a $2.2 \mathrm{~kb}$ deletion encompassing exon 3 of the $h M S H 2$ gene while the remaining two identified mutations have already been described in the ICG-HNPCC database (http://www.nfdht.nl (ICG-HNPCC mutation database). 

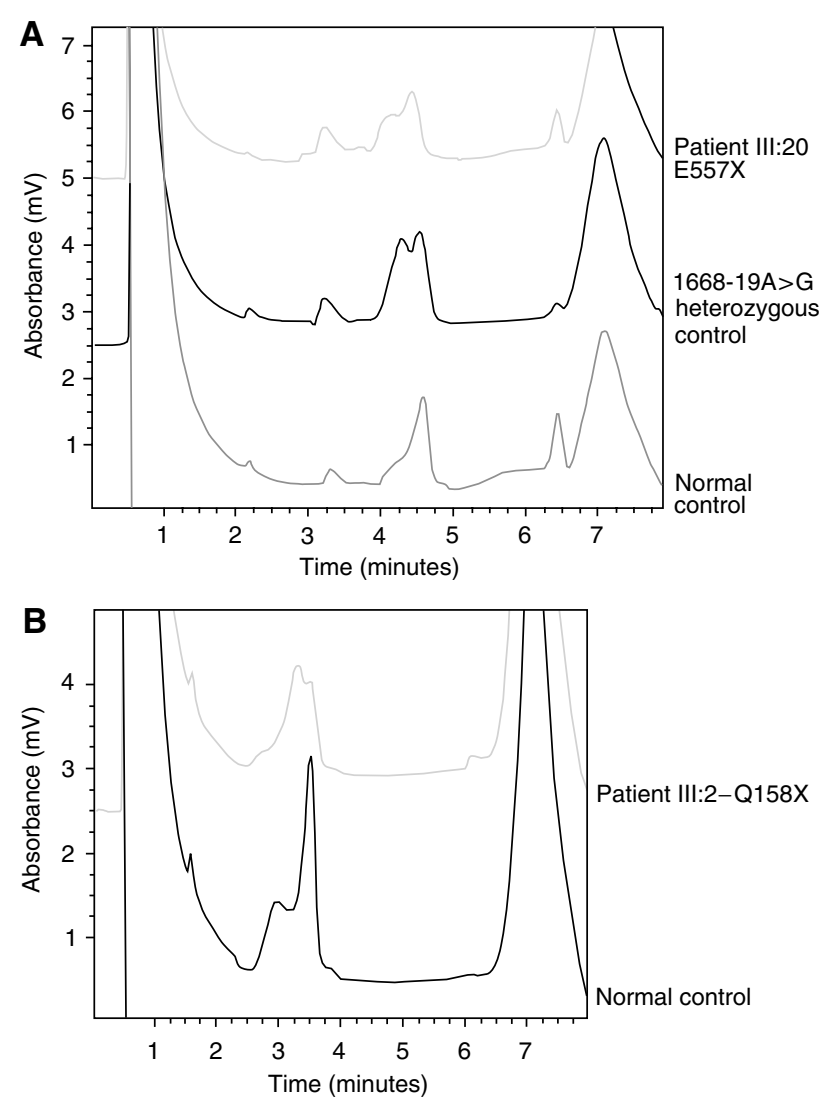

Figure 2 dHPLC analysis of two of the mutations identified: (A) E557X, (B) Q I58X. Patient number refers to the pedigrees in Figures IA and B, respectively.

\section{Families with novel mutations}

In family 3335 (Figure 1A and Table 1), the identified mutation is a single base substitution in exon 15 of the $h M L H 1$ gene. The mutation, 1669G $>\mathrm{T}$ (Figure 3A), converts the glutamine at codon 557 to a STOP codon. The mutation was originally identified in a patient (III:20,Figure $1 \mathrm{~A}$ and $2 \mathrm{~A}$ ) who had transitional cell carcinoma and CRC. Tumours of this patient were found to be MSI positive. MSI analysis of polyps resected from the patient's brother (III:18 Figure 1A) was negative. Individual III:18 has not developed a malignancy until the age of 65 . Mutation analysis of hMLH1 exon 15 revealed that he did not carry the mutation identified in his brother. The mutation was however identified in two more patients of this family (III:14 and III:8, Figure 1A). In the first patient a malignant melanoma had been diagnosed while the latter suffered from CRC.

In family 8344 (Figure 1B, Table 1), a mutation was suggested by dHPLC in the amplicon encompassing exon 3 of the $h M S H 2$ gene (Figure $2 \mathrm{~B}$ ). The mutation was shown by sequencing to be a $\mathrm{C}>\mathrm{T}$ substitution of nt 472 of the cDNA (Figure 3B) and results in substitution of a glutamine at position 158 by a STOP codon. The mutation was identified in a patient who was diagnosed with CRC at the age of 38 . His sister, who was also shown to carry the mutation developed a polyp of the large intestine at the age of 27. Their brother, who at the age of 37 is asymptomatic was found not to carry the family mutation.

In family 9663 (Figure 1C, Table 1), the proband (II:6, Figure 1C) was diagnosed with endometrial cancer at the age of 52 and CRC at 65. Her father (I:2, Figure 1C), brother (II:2, Figure 1C) and son (III:3, Figure 1C) also suffered from CRC while her niece (III:1, Figure 1C) died from endometrial cancer at the age of 34.
Denaturing high-performance liquid chromatography analysis revealed a mutation in exon 11 of $h M S H 2$. Sequencing showed this to be a 1704_1705delAG, which results in frameshift and creates a stop codon at 570 (Figure 3C). The mutation was also identified in the proband's son (III:3, Figure 1C), and one of her daughters (III:6, Figure 1C) who at the age of 44 is asymptomatic.

The patient from family 10107 (Figure 1D, Table 1) was first diagnosed with cancer of the ovaries at the age of 25 , followed by endometrial cancer at 36 , cancer of the urinary tract at 57 and CRC at 59. In addition, there were other cases of CRC, cancer of the eye, breast, endometrium, prostate and melanoma in the family. Sequencing of exon 6 of $h M S H 2$ revealed a G $>$ T substitution at the last base of the exon (nt 1076). In order to confirm the effect of this mutation, that is, whether it results in a splicing defect or substitution of the amino acid by a stop codon, RT-PCR and sequencing was carried out. These showed that the mutation results in substitution of an arginine residue by a stop codon at 359 (Figure 3D). No other family members were available for analysis.

\section{Large genomic rearrangements}

In family 7562 (Figure 1E, Table 1), MLPA analysis for screening of large genomic rearrangements revealed a deletion comprising exon 3 of the $h M S H 2$ gene. Long-range PCR using primers located in introns 2 and 4 (Figure 4) confirmed the deletion, which was found to be $2.2 \mathrm{~kb}$ long (Figure 4B). Subsequent fine mapping of the deletion breakpoints using a mixture of restriction endonucleases (Figure 4C) allowed the design of a new primer suitable for sequencing of the breakpoints. These were shown to be located in two Alu repeats in introns $2(A l u S g)$ and $3(A l u S x)$, respectively, sharing $78 \%$ homology. The deletion was flanked by 21 bases of complete homology. It is an in-frame deletion and results in the absence of 93 aa residues from the resulting protein product. The proband was a female patient who was diagnosed with CRC at the age of 35. The patient's father had died from CRC, her sister was diagnosed with endometrial cancer at the age of 45 and her brother developed CRC at the age of 42 . The mutation was later identified in the siblings of the patient and in her daughter who at the age of 29 years is an asymptomatic carrier. MSI analysis of tumour DNA from the proband was found to be negative.

\section{Families with known mutations}

In family 5838 (Figure 1F, Table 1), 676C $>\mathrm{T}$ was identified by sequencing in exon 8 of the $h M L H 1$ gene. The mutation results in the substitution of an arginine codon at position 226 by a stop codon and has previously been described by others (Moslein et al, 1996; Wehner et al, 1997). It was originally identified in a patient who had been diagnosed with CRC at the age of 49 (IV:1 in Figure $1 \mathrm{~F}$ ) who came from a family with multiple cases of CRC, two cases of endometrial cancer, both of whom carry the mutation, in addition to cancer of the larynx and the stomach.

In family 8902 (Figure 1G, Table 1), there were three cases of $\mathrm{CRC}$, three cases of gynaecological cancers and one individual for whom no information of cancer type was available. Denaturing high-performance liquid chromatography analysis identified a mutation in exon 13 of the $h M S H 2$ gene, whose sequencing was shown to be $\mathrm{C}>\mathrm{T}$ mutation at nucleotide 2131 , resulting in substitution of the arginine at codon 711 by a stop codon. This mutation has been previously described by others (Kurzawski et al, 2002).

\section{DISCUSSION}

In this study we present mutation analysis of the $h M L H 1$ and $h M S H 2$ genes implicated in the HNPCC syndrome in a cohort of nine Greek families at high risk of having HNPCC. Two of the 

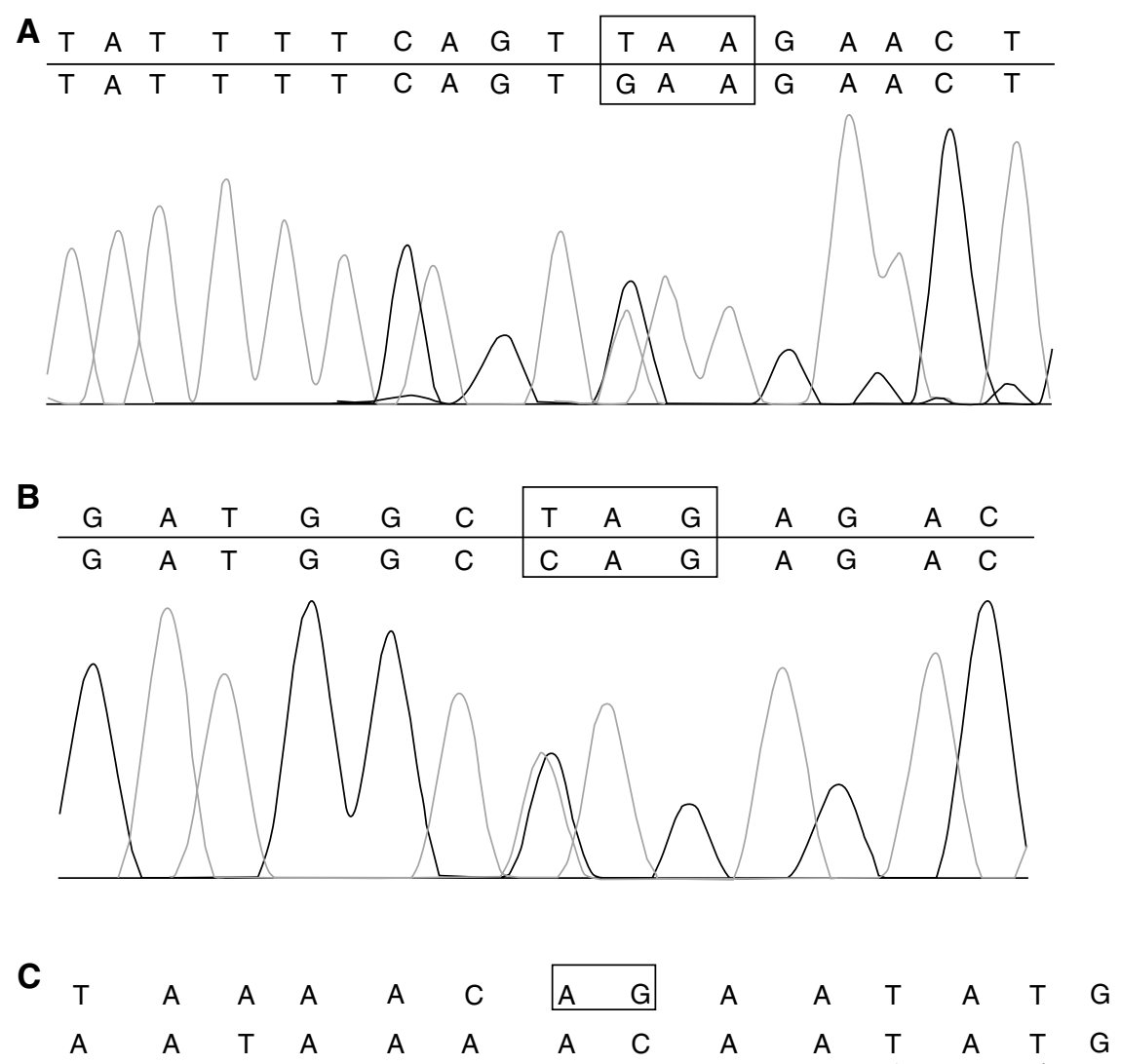
$\begin{array}{llllllllllllll}A & A & T & A & A & A & A & C & A & A & T & A & T & G\end{array}$

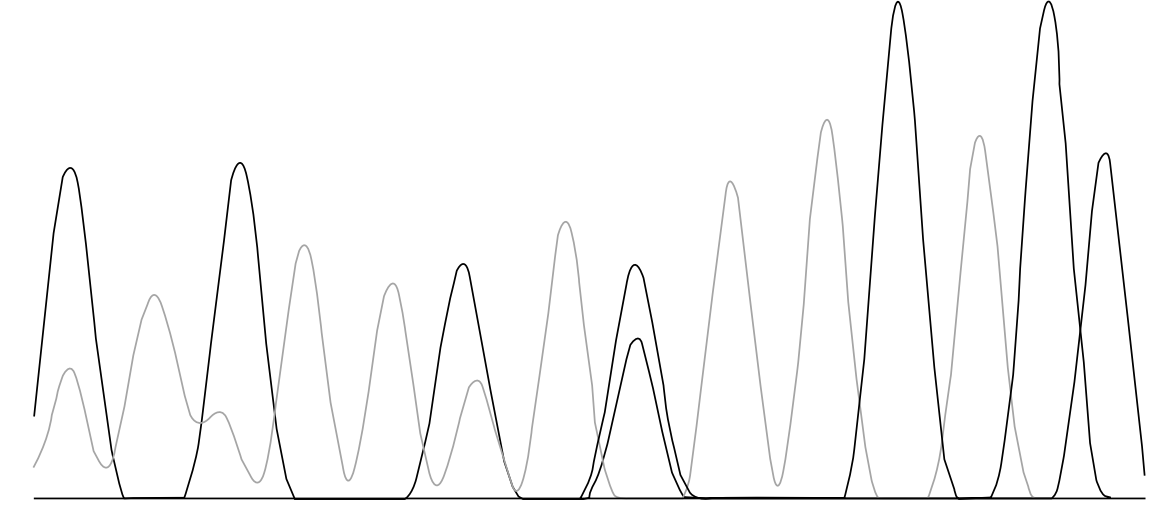

D

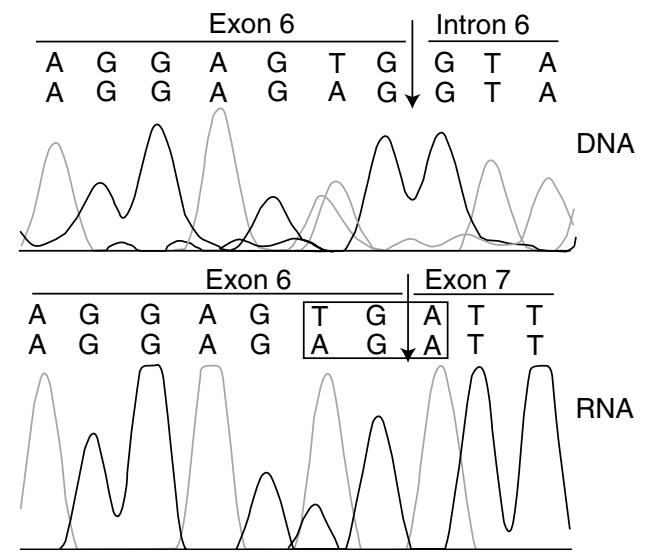

Figure 3 Chromatograms of novel mutations detected in this study. (A) E557X and (B) QI58X. The box indicates the mutated codon. (C) I704_I705 delAG. The box indicates the deleted nucleotides. (D) R359X. Top panel = sequencing analysis of genomic DNA, the arrow indicates the $3^{\prime}$ splice junction. Bottom panel $=$ sequencing analysis of cDNA, the box indicates the mutated codon. 


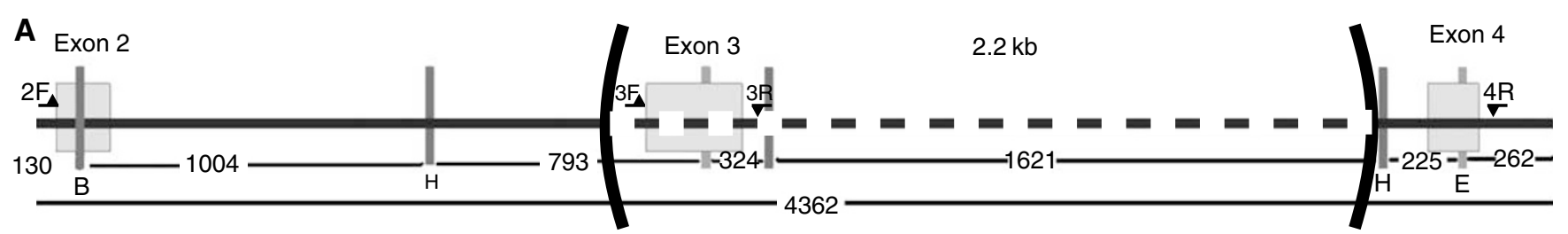

B

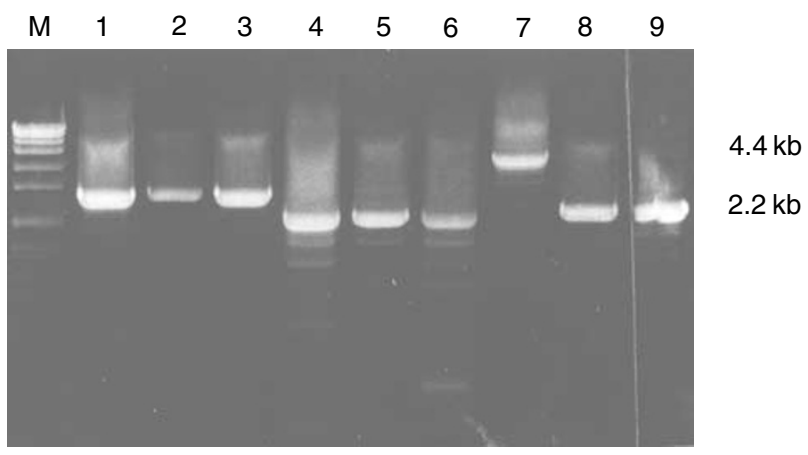

C

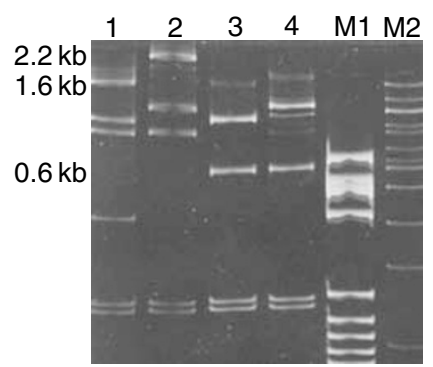

Figure 4 Characterisation of the $2.2 \mathrm{~kb}$ deletion identified in family 7562. (A) Schematic representation (not to scale) of the fragment of $h M S H 2$ gene amplified by long PCR showing the position of primers (horizontal arrows), exons (empty boxes), restriction endonuclease cleavage sites (vertical bars: $\mathrm{H}=$ HindlII, $\mathrm{E}=\mathrm{EcoRI}, \mathrm{B}=\mathrm{Bg} / \mathrm{II})$ and the deletion. (B) Long-range PCR using combinations of primers (from $\mathbf{A}$ ) spanning the repeat. $\mathrm{M}=$ molecular weight marker (VII, Boehringer Manheim, Germany), lanes I -3 using primers 2F and 3R, I = normal DNA, 2-3= patient DNA; lanes 4-6 using primers 3F and 4R, $4=$ normal DNA, 5-6 = patient DNA; lanes 7-9 using primers $2 \mathrm{~F}$ and $4 \mathrm{R}, 7=$ normal DNA, 8-9= patient DNA. (C) Restriction endonuclease digestion of PCR products from B with HindllI, EcoRI and Bglll. The bands containing exon 3 (2.3 kb in lane I and I.6 kb in lane 2) have disappeared and a new band $0.6 \mathrm{~kb}$ in length resistant to digestion with any of the three enzymes appears in the mutant sample (lanes 3 and 4 ). I: normal control digested with EcoRI/ HindlII/BgllI. 2: normal control digested with EcoRI/HindllI. 3: patient DNA digested with EcoRI/HindIII/Bglll. 4: patient DNA digested with EcoRI/HindIII. Lane MI: molecular weight marker V (Boehringer Manheim, Germany). Lane M2: Molecular weight marker 100 bp (New England Biolabs).

families do not strictly conform to the Amsterdam II criteria. Family 8344 (Figure 1B) meets the Bethesda criteria since cancer was diagnosed in the proband at the age of 38. Family 9659 (Figure 1I) was included in the analysis due to the number of affected members (four individuals with CRC and one case of endometrial cancer). The pathogenic mutation was identified in seven out of nine (78\%) families, including also one of the nonAmsterdam families (8344). This percentage compares well with other studies (Caluseriu et al, 2001; Wagner et al, 2003). However, it should be stressed that the accuracy and reliability of family history provided by patients and their relatives may not always be accurate and may therefore misguide researchers in the assignment of a family into a particular risk status group.

Interestingly, the majority of mutations (five out of seven, i.e. $77.7 \%$ ) identified in this study are located in the $h M S H 2$ gene. Although our sample group is quite small, this finding is in contrast with previous studies where the majority of pathogenic mutations associated with HNPCC have been identified in $h M L H 1$ (Peltomäki and Vasen, 1997; Wagner et al, 2003). Furthermore, four of the six single-point substitutions/small deletions are novel mutations, not previously described in the ICG-HNPCC mutation database (http://www.nfdht.nl). All single-point substitutions/ small deletions identified in this study are predicted to introduce premature stop codons in the gene sequence, therefore, resulting in truncated protein products. One of the novel mutations occurs at the last base of exon 6 of the $h M S H 2$ gene. The effect of this mutation on the protein was further investigated using RT-PCR and sequencing, showing that the mutation results in substitution of an arginine residue by a stop codon at 359 . This, in addition to, segregation of these novel mutations with the disease phenotype in the majority of cases confirms their pathogenic nature. One individual in each of the families, 7562, 8902 and 9663 in Table 1, was found to be an asymptomatic carrier. However, all three individuals are relatively young, 29, 14 and 44, respectively, while the average age at onset of the disease is quoted as being $\sim 45$ years of age according to the Amsterdam II criteria (Vasen et al, 1999). Furthermore, the lifetime risk of developing CRC in carriers of an MMR gene mutation is $~ 80 \%$ (Vasen et al, 1996; Aarnio et al, 1999).

The mutations identified in this and other studies are scattered throughout the two genes, with no obvious phenotype-genotype correlation. This, in addition to identification of both single-point substitutions and small deletions, as well as a $2.2 \mathrm{~kb}$ deletion, necessitates screening of the entire genes both for single-point mutations and small insertions/deletions as well as large genomic rearrangements. Even in this small cohort of patients genomic rearrangements account for $14.2 \%$ of identified mutations. Our results, therefore, indicate the importance of applying a variety of 
molecular biology techniques in order to identify inactivating mutations in high-risk patients.

Another interesting point emerging from our study of Greek HNPCC families is that a unique mutation was identified in each kindred. This is in contrast to other populations such as the Finnish where two mutations account for $>50 \%$ of the HNPCC families (Nystrom-Lahti et al, 1995).

Clinical diagnosis of HNPCC is not always easy as there is no clear phenotype associated with the disorder as is the case with other cancer predisposition syndromes such as familial adenomatous polyposis (Mihalatos et al, 2003b). Besides the spectrum of cancers characteristic of HNPCC, MSI is considered as one of the hallmark diagnostic features of HNPCC-related cancers (Boland et al, 1998). However, in this study, a pathogenic mutation was identified in the $h M S H 2$ gene in a patient whose CRC tumour was found to be microsatelite stable (family 7562). This could be explained by the absence of enough cancerous material in the sample analysed. However, if MSI analysis were a strict criterion in the inclusion of patients for genetic analysis, this patient would have been excluded. This finding stresses the need for use of a combination of criteria in the selection of patients suitable for mutation screening.

The reason for the interfamilial variability in the phenotypic manifestation of HNPCC is still not clear. However, use of DNA microarray analysis should soon shed some light as to the genetic factors that may act as modifiers in the disease phenotype predicted by the detection of germline mutations in MMR genes.

In summary, we have analysed nine families at high risk of carrying mutations in one of the MMR genes. The pathogenic mutation was identified in seven of the families. Three of the mutations identified are novel single base nonsense mutations, while a novel small deletion also resulting in premature termination has been identified. Finally, two previously described nonsense mutations and a $2.2 \mathrm{~kb}$ deletion in $h M S H 2$ were also identified. The results presented here provide the spectrum of mutations responsible for HNPCC for the first time in the Greek population, underscoring the differences observed in different geographic populations.

\section{ACKNOWLEDGEMENTS}

This work is supported by STAVROS NIARCHOS FOUNDATION FOR CHARITY and 'HYGEIA' Diagnostic \& Therapeutic Center of Athens. We thank all the clinicians who referred patients for this study and Dr Nicola Andrew of the Human Genetics Unit, Tayside University Hospitals NHS Trust, Dr Waltraut Friedl of the Institut Für Humangenetik, Rheinische Friedrich-Wilhems-Universität and Dr Alessandra Viel of the Centro di Riferimento Oncologico, Instituto Nazionale Tumori - Aviano for kindly donating control samples for establishing the methodology used for this study.

\section{REFERENCES}

Aarnio M, Sankila R, Pukkala E, Salovaara R, Aaltonen LA, de la Chapelle A, Peltomaki P, Mecklin JP, Jarvinen HJ (1999) Cancer risk in mutation carriers of DNA-mismatch-repair genes. Int J Cancer 81: 214-218

Boland CR, Thibodeau SN, Hamilton SR, Sidransky D, Eshleman JR, Burt RW, Meltzer SJ, Rodriguez-Bigas MA, Fodde R, Ranzani GN, Srivastava S (1998) A National Cancer Institute Workshop on Microsatellite Instability for cancer detection and familial predisposition: development of international criteria for the determination of microsatellite instability in colorectal cancer. Cancer Res 58: 5248-5257

Caluseriu O, Cordisco EL, Viel A, Majore S, Nascimbeni R, Pucciarelli S, Genuardi M (2001) Four novel MSH2 and MLH1 frameshift mutations and occurrence of a breast cancer phenocopy in hereditary nonpolyposis colorectal cancer. Hum Mutat 17: 521

Gille JJ, Hogervorst FB, Pals G, Wijnen JT, van Schooten RJ, Dommering CJ, Meijer GA, Craanen ME, Nederlof PM, de Jong D, McElgunn CJ, Schouten JP, Menko FH (2002) Br J Cancer 87: 892 -897, doi: 10.1038/ sj.bjc. 6600565

Hardisson D, Moreno-Bueno G, Sanchez L, Sarrio D, Suarez A, Calero F, Palacios J (2003) Tissue microarray immunohistochemical expression analysis of mismatch repair (hMLH1 and hMSH2 genes) in endometrial carcinoma and atypical endometrial hyperplasia: relationship with microsatellite instability. Mod Pathol 16: $1148-1158$

Hendriks Y, Franken P, Dierssen JW, De Leeuw W, Wijnen J, Dreef E, Tops C, Breuning M, Brocker-Vriends A, Vasen H, Fodde R, Morreau H (2003) Conventional and tissue microarray immunohistochemical expression analysis of mismatch repair in hereditary colorectal tumors. Am J Pathol 162: $469-477$

Holinski-Feder E, Muller-Koch Y, Friedl W, Moeslein G, Keller G, Plaschke J, Ballhausen W, Gross M, Baldwin-Jedele K, Jungck M, Mangold E, Vogelsang H, Schackert HK, Lohsea P, Murken J, Meitinger T (2001) J Biochem Biophys Methods 47: 21-32, doi:10.1016/S0165$022 \mathrm{X}(00) 00148-2$

Jourdan F, Sebbagh N, Comperat E, Mourra N, Flahault A, Olschwang S, Duval A, Hamelin R, Flejou JF (2003) Tissue microarray technology: validation in colorectal carcinoma and analysis of p53, hMLH1, and hMSH2 immunohistochemical expression. Virchows Arch 443: 115-121

Kurzawski G, Safranow K, Suchy J, Chlubek D, Scott RJ, Lubinski J (2002) Mutation analysis of MLH1 and MSH2 genes performed by denaturing high-performance liquid chromatography. J Biochem Biophys Methods 51: $89-100$
Leach FS, Nicolaides NC, Papadopoulos N, Liu B, Jen J, Parsons R, Peltomaki P, Sistonen P, Aaltonen LA, Nystrom-Lahti M (1993) Mutations of a mutS homolog in hereditary nonpolyposis colorectal cancer. Cell 75: 1215-1225

Lynch HT, de la Chapelle A (1999) Genetic susceptibility to non-polyposis colorectal cancer. J Med Genet 36: $801-818$

Mihalatos M, Apessos A, Triantafillidis JK, Kosmidis PA, Fountzilas G, Agnantis NJ, Yannoukakos D, Nasioulas G (2003a) Evaluation of dHPLC in mutation screening of the APC gene in a Greek FAP Cohort. Anticancer Res 23: 2691-2696

Mihalatos M, Danielides I, Beloyianni J, Harokopos E, Kalimanis G, Tsiava M, Triantafillidis JK, Kosmidis PA, Fountzilas G, Agnantis NJ, Yannoukakos D, Nasioulas G (2003b) Novel mutations of the APC gene in Greek Familial Adenomatous Polyposis patients. Cancer Genet Cytogenet 141: 65-70

Moslein G, Tester DJ, Lindor NM, Honchel R, Cunningham JM, French AJ, Halling KC, Schwab M, Goretzki P, Thibodeau SN (1996) Microsatellite instability and mutation analysis of hMSH2 and hMLH1 in patients with sporadic, familial and hereditary colorectal cancer. Hum Mol Genet 5: $1245-1252$

Nystrom-Lahti M, Kristo P, Nicolaides NC, Chang SY, Aaltonen LA, Moisio AL, Jarvinen HJ, Mecklin JP, Kinzler KW, Vogelstein B (1995) Founding mutations and Alu-mediated recombination in hereditary colon cancer. Nat Med 1: $1203-1206$

Papadopoulos N, Lindblom A (1997) Molecular basis of HNPCC: mutations of MMR genes. Hum Mutat 10: 89-99

Peltomäki P, Vasen HF (1997) Mutations predisposing to hereditary nonpolyposis colorectal cancer: database and results of a collaborative study. The International Collaborative Group on Hereditary Nonpolyposis Colorectal Cancer. Gastroenterology 113: 1146-1158

Rodriguez-Bigas MA, Boland CR, Hamilton SR, Henson DE, Jass JR, Khan PM, Lynch H, Perucho M, Smyrk T, Sobin L, Srivastava S (1997) A National Cancer Institute Workshop on Hereditary Nonpolyposis Colorectal Cancer Syndrome: meeting highlights and Bethesda guidelines. J Natl Cancer Inst 89: 1758 - 1762

Schouten JP, McElgunn CJ, Waaijer R, Zwijnenburg D, Diepvens F, Pals G (2002) Relative quantification of 40 nucleic acid sequences by multiplex ligation-dependent probe amplification. Nucleic Acids Res 30: e57

Vasen HF, Watson P, Mecklin JP, Lynch HT, the ICG - HNPCC (1999) New clinical criteria for hereditary nonpolyposis colorectal cancer (HNPCC, 
HNPCC in Greece

A Apessos et al

Lynch syndrome) proposed by the International Collaborative group on HNPCC. Gastroenterology 116: $1453-1456$

Vasen HF, Wijnen JT, Menko FH, Kleibeuker JH, Taal BG, Griffioen G, Nagengast FM, Meijers-Heijboer EH, Bertario L, Varesco L, Bisgaard ML, Mohr J, Fodde R, Khan PM (1996) Cancer risk in families with hereditary nonpolyposis colorectal cancer diagnosed by mutation analysis. Gastroenterology 110: 1020-1027

Wagner A, Barrows A, Wijnen JT, van der Klift H, Franken PF, Verkuijlen P, Nakagawa H, Geugien M, Jaghmohan-Changur S, Breukel C, MeijersHeijboer H, Morreau H, van Puijenbroek M, Burn J, Coronel S, Kinarski Y, Okimoto R, Watson P, Lynch JF, de la Chapelle A, Lynch HT, Fodde R (2003) Molecular analysis of hereditary nonpolyposis colorectal cancer in the United States: high mutation detection rate among clinically selected families and characterization of an American founder genomic deletion of the MSH2 gene. Am J Hum Genet 72: 1088-1100

Watson P, Lynch HT (1993) Extracolonic cancer in hereditary nonpolyposis colorectal cancer. Cancer 71(3): 677-685

Wehner M, Buschhausen L, Lamberti C, Kruse R, Caspari R, Propping P, Friedl W (1997) Hereditary nonpolyposis colorectal cancer (HNPCC) eight novel germline mutations in hMSH2 or hMLH1 genes. Hum Mutat 10: $241-244$

Wijnen J, van der Klift H, Vasen H, Khan PM, Menko F, Tops C, Meijers Heijboer H, Lindhout D, Moller P, Fodde R (1998) MSH2 genomic deletions are a frequent cause of HNPCC. Nat Genet 20: 326-328 